\title{
Na srebrnym globie Jerzego Żuławskiego w zwierciadle ekokrytyki
}

\section{Abstrakt:}

Artykuł poświęcony jest analizie i interpretacji powieści Jerzego Żuławskiego $\mathrm{Na}$ srebrnym globie. Rękopis z Księżyca (1903) z perspektywy ekokrytycznej. W utworze podróż na Księżyc staje się ucieczką od destrukcyjnej cywilizacji chylącej się ku upadkowi. Autor tekstu zwraca szczególną uwagę na relację człowiek - świat natury, która diametralnie zmieniła się na skutek postępującej rewolucji przemysłowej. Mimo ucieczki bohaterowie tęsknią za Ziemią, nieustannie porównując pejzaż księżycowy z ziemskim, co potęguje w nich uczucie melancholii.

\section{Słowa kluczowe:}

ekokrytyka, Jerzy Żuławski, literatura młodzieżowa, literatura fantastycznonaukowa, Na srebrnym globie. Rękopis z Księżyca

\section{On the Silver Globe by Jerzy Żuławski in the Mirror of Ecocriticism}

\section{Abstract:}

The article is devoted to the analysis and interpretation of Jerzy Żuławski's novel On the Silver Globe (1903) from an ecocritical perspective. The journey to the moon becomes here an escape from the destructive civilisation that is falling. The author of the paper pays special attention to the human-nature relationship, which has dramatically changed as a result of the ongoing industrial revolution. Despite the escape, the characters miss Earth, constantly comparing the lunar and terrestrial landscapes, which enhances their feelings of melancholy.

Key words:

ecocriticism, Jerzy Żuławski, young adult literature, science fiction literature, On the Silver Globe

* Dariusz Piechota - dr, pracuje na Wydziale Filologicznym Uniwersytetu w Białymstoku. Członek Laboratorium Animal Studies - Trzecia Kultura, nauczyciel w Zespole Szkół nr 3 w Puławach. Jego zainteresowania badawcze obejmują literaturę drugiej połowy XIX wieku, ekokrytykę, animal studies, najnowszą prozę popularną. Kontakt: darekpiechota@o2.pl. 


\section{Wprowadzenie}

$\mathbf{U}$ schyłku XIX i na początku XX wieku twórcy literatury dla dzieci i młodzieży wprowadzali nowe obszary tematyczne, które nie były podporządkowane pozytywistycznemu paradygmatowi z utylitaryzmem i dydaktyzmem na czele (Hutnikiewicz, 2002, s. 369-370). Na skutek rosnącego zainteresowania psychologią pisarze rezygnowali z dydaktyzmu oraz uproszczonego wizerunku świata. Wprowadzając elementy baśniowe, zwracali uwagę na zróżnicowane życie wewnętrzne bohaterów, odwoływali się do wyobraźni, fantazji oraz wieloznaczności (Ihnatowicz, 2000, s. 303). Rzeczywistość przestała być jednowymiarowa, a podejmowane przez bohaterów podróże (typowe dla powieści przygodowej, robinsonady czy utopii) obejmowały nie tylko glob ziemski, lecz także cały wszechświat. Motyw ten był często wykorzystywany w powieściach fantastycznonaukowych (Makuch, 2015, s. 31-46), a za ich prekursora (Leszczyński, 2002, s. 316) uznaje się Władysława Umińskiego, autora Balonem do bieguna (1894) czy W nieznane światy (1895).

Szczególną popularnością wśród młodzieży cieszyła się opublikowana w 1903 roku powieść Na srebrnym globie. Rękopis z Księżyca Jerzego Żuławskiego (1987; zob. Podraza-Kwiatkowska, 2001, s. 256). Artur Hutnikiewicz (2002, s. 372) podkreślał, że mimo licznych wątków społecznych, filozoficznych i historiozoficznych pozycja ta przez długi czas była poszukiwaną lekturą wśród nastoletnich czytelników, wyprzedzając beletrystykę astronomiczną ${ }^{1}$.

Przypomnijmy, że Żuławski rozpoczyna pracę nad pierwszym tomem Trylogii księżycowej (pozostałe to Zwycięzca, 1910, oraz Stara Ziemia, 1911), której bohaterowie decydują się opuścić Ziemię i rozpocząć egzystencję na Księżycu, w 1901 roku. Ta eskapistyczna wyprawa oddaje reminiscencje pesymistycznych nastrojów schyłku XIX wieku. Postępujące procesy industrializacyjne

1 Warto podkreślić, iż popularność Na srebrnym globie przetrwała wojnę, a jej pierwsze powojenne krajowe wydanie ukazało się w 1946 roku (kolejne zaś w 1956, co zapewne spowodowane było kulturową zapaścią w okresie socrealizmu). Nawiasem mówiąc, powieść Jerzego Żuławskiego została także zekranizowana przez Andrzeja Żuławskiego (1987; zob. także Panasiuk, 2013). Zainteresowanie twórczością autora Trylogii księżycowej nasiliło się w XXI wieku, o czym świadczy monografia Zasługi Jerzego Żuławskiego i jego rodu dla literatury i kultury polskiej XX wieku pod redakcją Eugenii Łoch i Dariusza Trześniowskiego (2011), w której pojawiły się trzy szkice poruszające problematykę Trylogii księżycowej (Beaty Utkowskiej, Janiny Szcześniak, Elżbiety Nazaruk). Przypomnijmy, że w 1976 roku pojawiła się pierwsza monografia poświęcona pisarzowi pt. Jerzy Żuławski: życie i twórczość. Referaty i materiały Sesji Naukowej pod redakcją Łoch (1976). 
oraz urbanizacyjne, wraz z gwałtownym przyrostem nowych mieszkańców w metropoliach przemysłowych, nasilały uczucie osaczenia. Szybko dostrzeżono, iż nowoczesna cywilizacja zagrażała jednostce oraz kulturze (Podraza-Kwiatkowska, 2001, s. 43-44). Okazało się, że postęp moralny nie idzie w parze ze wzrostem dóbr materialnych społeczeństwa. Co więcej, ostrzegano przed duchową degeneracją człowieka zanurzonego w świecie maszyn (Szurek, 1988, s. 186). Niepokój potęgowany był również przez dynamiczny rozwój fizyki w ostatnich dwóch dekadach XIX wieku. Obawiano się, że w jednym z licznych europejskich laboratoriów trwają prace nad śmiercionośną technologią, która znajdzie zastosowanie militarne i odmieni sposób, w jaki toczone są wojny (Oramus, 2020, s. 113). Nie dziwi zatem fakt, iż u schyłku epoki wiktoriańskiej pojawiły się futurystyczne utwory o charakterze katastroficznym, zapowiadające międzynarodowy konflikt zbrojny ${ }^{2}$.

Narastający kryzys wartości potęgował zagubienie człowieka, egzystującego u schyłku epoki pary i elektryczności, poszukującego celu oraz sensu życia. Nastroje pesymistyczno-dekadenckie korespondowały także z przekonaniem o nieuchronnym starzeniu się kultury europejskiej, o czym wspominał w fundamentalnym dziele Zmierzch Zachodu Oswald Spengler (1918/2014). Niemiecki filozof rozpoczął pisanie rozprawy pod koniec XIX wieku i twierdził, iż rozwinięty Zachód stał się cywilizacją zdegenerowaną, czekającą na nowych „barbarzyńców” ze Wschodu, którzy zajmą jej miejsce (Oramus, 2020, s. 114).

Nieco wcześniej Jan Bloch (1893) opublikował pierwszy tom cyklu rozpraw Przyszła wojna, jej ekonomiczne przyczyny i skutki, pisany z perspektywy pacyfisty zatroskanego o los Europy (Paczoska, 2008, s. 145). Autor, analizując potencjał militarny świata, przewidywał, że przyszła wojna może doprowadzić do globalnej katastrofy i anarchii. Narastające niepokoje potęgowane były także przez anomalie atmosferyczne. Na początku szóstego tomu Bloch (1899) pisze:

Naturaliści utrzymują, że w atmosferze ziemi od czasu dostrzec się daje tak zwany pył kosmiczny. To ten pył właśnie zmienia barwę stropu niebieskiego, krwawi promienie słoneczne, wdziera się do naszych domostw i płuc, działa szkodliwie na żywe organizmy i, dostając się nawet na gór szczyty, zostawia ślad swój na ich dziewiczym śniegu (s. i).

2 The Great War of 189-: A Forecast [Wielka wojna roku 189-: Prognoza] P. H. Colomba (1893); The Captain of the „Mary Rose” [Kapitan „Mary Rose”] Williama Lairda Clowesa (1892); The Final War [Wojna ostateczna] Louisa Tracy'ego (1896); The Crack of Doom [Dzień gniewu] Roberta Cromiego (1895/2015) czy Wojna światów George’a Herberta Wellsa (1898/1987). O tych utworach pisze Dominika Oramus (2020, s. 116). 
Popularnością cieszyły się również teorie o szybkim wygasaniu słońca, a tym samym - zamarzaniu naszej planety (Podraza-Kwiatkowska, 2001, s. 45). Lęk przed śmiercią czy uprzedmiotowieniem, osłabienie woli, porzucenie wiary w przyszłość, melancholia były powszechne w świadomości pokolenia epoki fin de siècle. Fascynacje modernistów wątkami katastroficznymi, zapowiadającymi nadciągający kres cywilizacji, stały się początkiem poszukiwania azylu, lokalizowanego poza globem ziemskim.

Zainteresowanie podróżami międzyplanetarnymi nasiliło się w XIX wieku. Przypomnijmy, że w 1835 roku John Herschel, przebywający na Przylądku Dobrej Nadziei w Afryce Południowej, skierował teleskop w stronę Księżyca, dostrzegając na nim, jak dowodził, nie tylko pole ciemnoczerwonych kwiatów, stada czworonogów przypominających bizony, jednorożca, ale również ludzi nietoperzy (Morrison, 1969; Sroczyńska, 2018, s. 30). Sensacyjne doniesienia szybko zostały rozpowszechnione przez prasę bulwarową, której nagłówki („Skrzydlaci ludzie na Księżycu!”) przyciągały kolejnych czytelników. Opisy odkryć Herschela sprzedawały się szybciej niż Biblia (s. 31). Na opublikowanym cyklu księżycowym zawrotną sumę zarobił redaktor The Sun Richard Adams Locke, który następnie założył własną gazetę New Era (s. 33). Mimo że doniesienia Herschela zostały zakwestionowane przez środowisko naukowe, zyskały popularność wśród twórców science fiction, snujących wizje życia na innych plantach (np. w Wojnie światów Wellsa z 1898 roku). Wątek skrzydlatych istot mieszkających na Księżycu pojawił się zaś m.in. w powieści Podróż po Księżycu odbyta przez Serafina Bolińskiego Teodora Tripplina (1858). Według pisarza to tam przebywają dusze zmarłych Ziemian, oczekując na przeprowadzkę do życia wiecznego na innej planecie.

Podróże międzyplanetarne występują również w utworach Juliusza Verne’a (Z Ziemi na Księżyc, 1865, i Wokół Księżyca, 1870). Bohaterowie tych powieści są przekonani, iż Księżyc zestarzał się szybciej niż Ziemia, dlatego też miejsce to nie nadaje się do zamieszkania z powodu niekorzystnych warunków atmosferycznych. Według Verne’a podobny los czeka naszą planetę i w przyszłości Ziemianie będą zmuszeni do poszukiwania nowego miejsca do dalszej egzystencji. Z kolei w utworze Pierwsi ludzie na Księżycu Wellsa (1901/1991) bohaterowie odkrywają, że ciało niebieskie jest zamieszkiwane przez wysoko rozwiniętą cywilizację owadopodobnych stworzeń. Jego wnętrze wypełnia złoto, co staje się początkiem współpracy handlowej z tubylcami.

W nurt literatury zainspirowanej fascynacją podróżami międzyplanetarnymi wpisuje się Na srebrnym globie Żuławskiego. W niniejszym szkicu pragnę scharakteryzować powieść autora Trylogii księżycowej z perspektywy 
ekokrytycznej ${ }^{3}$. Warto podkreślić, iż pod koniec XIX wieku zaczęto dostrzegać destrukcyjny wpływ działalności człowieka na środowisko naturalne. Powszechne stały się narastające społeczne lęki przed zanieczyszczeniem powietrza, zatruciem wody czy zniszczeniem krajobrazu (Paczoska, 2010, s. 65). Twórcy epoki wiktoriańskiej (m.in. John Ruskin, William Morris), przeciwstawiając się rozprzestrzeniającej się cywilizacji przemysłowej, zaproponowali alternatywny projekt przemiany świata, zakładający powrót do utraconej więzi z przyrodą. Marzenie o epoce preindustrialnej odzwierciedlały utopie agrarne, w których to życie człowieka wpisane było w odwieczny porządek panujący w naturze, a jego relacje $z$ otaczającym światem opierały się na symbiozie i wzajemnym szacunku (Fiedorczuk, 2015, s. 74; Pułka, 1996, s. 79). Należy zatem spojrzeć skrótowo na historię XIX wieku, ze szczególnym uwzględnieniem relacji człowiek - świat natury, która diametralnie zmieniła się na skutek gwałtownie postępującej rewolucji przemysłowej ${ }^{4}$.

3 Ekokrytykę definiuję jako nowy sposób widzenia świata, opierający się na myśleniu relacyjnym, podkreślający „wzajemne związki, współbycie człowieka i środowiska, bytów i istot ludzkich i nie-ludzkich" (Domańska, 2013, s. 15), zrywający z antropocentrycznym paradygmatem opisu rzeczywistości. Ekokrytyka bada zależności między organizmami a środowiskiem, a sposób postrzegania świata, który z niej wypływa, jak pisze Julia Fiedorczuk (2015), może wyznaczać pewne kierunki działania, czyli stanowić podstawy etyki: „Ekokrytyka przejmuje tę ekologiczną optykę. Przeciwstawia się formalizmowi uznającemu tekst za autonomiczny twór estetyczny pozbawiony wszelkich związków z pozajęzykową rzeczywistością" (s. 17-18). Jest zatem w coraz większym stopniu praktyką interdyscyplinarną, prowadzi do zreformowania humanistyki począwszy od metodologii badań, a skończywszy na dydaktyce (s. 19). Na gruncie polskim pojawiły się kilka lat temu dwie inspirujące książki z zakresu ekokrytyki: Geopoetyka. Związki literatury i środowiska (Kronenberg, 2014) i Cyborg w ogrodzie. Wprowadzenie do ekokrytyki (Fiedorczuk, 2015). Wydano także dwa tomy zbiorowe poświęcone tej tematyce: Ekomodernizmy (Trześniewska, Piechota, 2016) oraz Ekokrytyka (Wojciechowski, 2018). Do ważniejszych opracowań dotyczących ekokrytyki należą ponadto: Humanistyka ekologiczna (Domańska, 2013); Biopolis - przyroda i miasto (Rybicka, 2018); Natura u kresu (ekocyd) (Ubertowska, 2013); „Mówić w imieniu biotycznej wspólnoty”. Anatomie i teorie tekstu środowiskowego/ekologicznego (Ubertowska, 2018). Z kolei w pracach Justyny Tabaszewskiej (2018) oraz Anny Barcz (2012) znajdują się podsumowania opracowań najważniejszych amerykańskich autorów tego nurtu.

4 O relacjach człowiek - środowisko naturalne w kontekście literatury drugiej połowy XIX wieku pisali m.in. następujący badacze: Barcz (2013), Ireneusz Gielata (2015, 2016), Ryszard Koziołek (2010, 2011), Dariusz Piechota (2016), Ewelina Rąbkowska (2017a, 2017b), Maciej Skowera (2016), Piechota i Agnieszka Trześniewska (2016), Anna Wietecha (2016). 


\section{Ekokrytyczny bilans wieku XIX}

W ostatniej dekadzie XIX wieku przekroczono próg globalnego zużycia energii pochodzącej z mineralnych paliw (Osterhammel, 2009/2013, s. 94). Na skutek intensywnej industrializacji już wcześniej nastąpiło zaburzenie równowagi panującej w ekosystemie, czego przejawem stały się m.in. atak szarańczy w Górach Skalistych (USA) w latach 70. i wybuchy wulkanów w Azji Południowo-Wschodniej, przyczyniające się do zniszczenia lasów oraz pól ryżowych. Częstym zjawiskiem były także powodzie oraz towarzyszące im klęski głodu i epidemie (s. 266-269).

Rozwijającemu się przemysłowi towarzyszyła deforestacja. Między 1850 a 1920 rokiem na świecie wycięto prawdopodobnie tyle samo lasów pierwotnych, ile w ponad dwukrotnie dłuższym okresie od 1700 do 1850 roku (Osterhammel, 2009/2013, s. 498). Nastąpiła również gwałtowna eksploracja lasów tropikalnych. Ich wyrąb w Indiach zaburzył funkcjonowanie pierwotnych społeczeństw oraz zwierząt, które zostały wygnane ze swojego środowiska naturalnego (s. 502). Budowa kolejnych linii kolejowych przyczyniła się do dewastacji naturalnych rezerwatów przyrody.

Od połowy XIX wieku gwałtownie wzrosła konsumpcja mięsa - dzięki opracowaniu nowoczesnych metod mrożenia, umożliwiających jego transport z Argentyny do Europy. W Chicago powstało industrialne inferno dla bydła, które zostało wnikliwie opisane w bestsellerowej powieści Grzęzawisko Uptona Sinclaira (1906/1949). Upowszechniło się również łowiectwo w mieszczańskich społecznościach, o którym pisze w Listach z podróży do Ameryki Henryk Sienkiewicz (1880). W epoce pary i elektryczności rozwinął się handel egzotycznymi zwierzętami ${ }^{5}$. Niejednokrotnie $\mathrm{w}$ trakcie transportu wiele $\mathrm{z}$ nich ginęło. Popularnością cieszył się handel futrami oraz kością słoniową, wykorzystywaną do produkcji noży, kul bilardowych czy klawiszy fortepianu. Nawiasem mówiąc, w latach 60. XIX wieku Wielka Brytania sprowadzała 550 ton kości słoniowej rocznie, co przyczyniło się do wyginięcia słoni w wielu regionach Afryki (Osterhammel, 2009/2013, s. 510). Masowo zabijano również nosorożce, których sproszkowany róg uchodził za afrodyzjak na Dalekim Wschodzie (s. 510). Moda na przyozdabianie kapeluszy strusimi piórami przyczyniła się do powstawania kolejnych farm, na których ptaki te były hodowane w nieludzkich warunkach. Dewastacji uległy także morskie ekosystemy. Myśliwi organizowali polowania na wieloryby, a w szczególności na kaszaloty, których olej

5 W latach 70. XIX wieku nosorożce można było kupić w Afryce Wschodniej za 160 marek i sprzedać w Europie za 6000 (Osterhammel, 2009/2013, s. 509). 
wykorzystywany był do produkcji najdroższych świec świata, fiszbiny zaś do produkcji gorsetów (s. 512).

Nie ulega wątpliwości, że epoka pary i elektryczności była wiekiem przemocy. Postępująca industrializacja oraz ekstensywna eksploatacja dzikich terenów stały się impulsem dla rodzącej się nowoczesnej świadomości ekologicznej, przejawiającej się choćby w postulatach ochrony terenów dziewiczych.

\section{Eksplorując przestrzeń Księżyca}

Na srebrnym globie wpisuje się po części w literaturę podróżniczą, w której to w centrum zainteresowania autora znajduje się egzotyczny ląd oraz panujące na nim warunki atmosferyczne. Przygotowując się do pisania powieści, Żuławski często odwiedzał Obserwatorium Krakowskie, gdzie z ogromnym zapałem obserwował Księżyc za pomocą lunety. Konsultował również swoje pomysły z astronomem Józefem Zajączkowskim (Kordylewski, 1987, s. 331; Trześniowski, 2003, s. 199). Zdobyte informacje stały się cennym źródłem, dzięki któremu pisarz przygotował mapę Księżyca, porządkującą i opisującą poszczególne jego regiony. Okazuje się, że nowa planeta to miejsce niezwykle zróżnicowane pod względem geograficznym; odnajdujemy tutaj nie tylko góry, doliny, równiny, lecz także morze, rzeki, strumyki.

Na uwagę zasługuje postać narratora, Jana Koreckiego, który z precyzyjną dokładnością rejestruje wędrówkę kosmonautów. Prowadzony przez niego dziennik łączy w sobie cechy typowe dla eseju autobiograficznego, reportażu podróżniczego, a nawet w niektórych fragmentach rozprawy popularnonaukowej, co jest charakterystyczne dla prozy adresowanej do dzieci i młodzieży, by wspomnieć o powieściach Doktor Muchołapski. Fantastyczne przygody w świecie owadów i Profesor Przedpotopowicz Erazma Majewskiego (1890, 1898; zob. także Trześniewska-Nowak, 2020). Opowieść Koreckiego przypomina amerykański gatunek nature writing, czerpiący tematycznie $\mathrm{z}$ historii naturalnej, w którym dominuje subiektywny zapis odbioru świata (Durczak, 2010, s. 20). Jej autor przeprowadza bezpośrednio badania terenowe, posługując się niekiedy techniką opisu naukowego. Protagonista dzieli się z czytelnikami wiedzą geograficzną i geologiczną, a jego opowieść o świecie natury zostaje przefiltrowana przez wrażliwość, wyobraźnię oraz intelekt narratora (s. 9), który niejednokrotnie odwołuje się również do tekstów kultury, takich jak Boska komedia Dantego Alighieri (1472/1978).

Kosmiczna podróż, która rozpoczyna się w Kongo, okazuje się totalną katastrofą. Bohaterowie bezpowrotnie tracą kontakt z Ziemią. Już od pierwszych 
chwil pobytu na Księżycu tęsknią za domem. Na uwagę zasługują same określenia planety (np. „świecący szklany upiór”; Żuławski, 1987, s. 30), które podkreślają postępującą na niej agonię. Poczucie odrealnienia potęgowane jest przez klimat panujący na północnym obszarze Księżyca. Marta w rozmowie z Koreckim stwierdza, iż „ma wrażenie, jakby się już stała duchem, pozbawionym ważkiego ciała” (s. 29).

Na początku pobytu Księżyc wydaje się martwą planetą, co koresponduje z nastrojem bohaterów. Lęk oraz strach przed nieznanym intensyfikuje grozę księżycowego pejzażu, w którego opisie dominują ostre kontrasty kolorystyczne:

Noc wprawdzie jest jasna, jaśniejsza bez porównywania od naszych - tam ziemskich nocy podczas pełni. Olbrzymi półkrąg Ziemi tkwi nad nami nieruchomie w czarnym niebie zenitu i zlewa białym światłem tę pustkę straszliwą wokół nas... W tym dziwnym świetle jest wszystko takie tajemnicze i martwe... I mróz... Oh! jaki straszny mróz! - Słońca! słońca! (Żuławski, 1987, s. 27).

Wszechogarniająca cisza oraz zastygające w bezruchu planety wywołują wśród bohaterów niepokój. To chwilowe zatrzymanie w czasie budzi skojarzenia $\mathrm{z}$ agonią. Okazuje się, iż jedynymi żywymi istotami we wszechświecie są kosmonauci. Żuławski, niejednokrotnie opisując relacje człowiek - środowisko, posługuje się hiperbolizacją, aby podkreślić dramatyzm zaistniałej sytuacji. Prześladujące „upiorne światło Ziemi” (s. 28) nieustannie przypomina bohaterom o utraconej więzi z planetą, która notabene urasta do rangi raju utraconego (Trześniowski, 2001).

Nie dziwi zatem fakt, że Ziemia staje się kluczowym punktem odniesienia dla bohaterów Żuławskiego. Nie zapominają o niej nawet w trakcie snu. Narrator w prowadzonym pamiętniku wspomina:

Zdawało mi się we śnie, że jestem jeszcze na Ziemi, w jakichś gajach zielonych i chłodnych, gdzie po śnieżnej murawie szemrał rozlany przeczysty potok. Po błękitnym niebie szły białe obłoki, słyszałem śpiew ptaków i brzęczenie owadów, i głos ludzi wracających z pola (Żuławski, 1987, s. 39).

W świadomości Koreckiego dominuje idylliczny obraz natury sprzed rewolucji przemysłowej, która to zaburzyła równowagę panującą w ekosystemie (Gifford, 2000, s. 219-222). W opisie tym pisarz posługuje się poetyką oniryczną oraz impresjonistyczną, zwracając uwagę na ulotne dźwięki, kolory i obrazy. Aluzje do polskiego, arkadyjskiego pejzażu pojawiają się niejednokrotnie w powieści Żuławskiego. Przywołajmy choćby epizod, w którym bohaterowie docierają do kamiennej pustyni: 
Hej! Jakże szalenie szybko przemknęło to moje życie na Ziemi. Dziwny taniec widm i wspomnień miałem na oczach: śniły mi się nadwiślańskie równiny i chmurne turnie Tatr - a wszystko zaludnione takim nieprzeliczonym orszakiem znajomych, drogich, a pożegnanych już na wieki... (Żuławski, 1987, s. 66).

Nieprzypadkowo we wspomnieniu narratora pojawiają się Tatry, które u schyłku XIX wieku stały się przestrzenią odrodzenia oraz oczyszczenia (Paczoska, 1996, s. 101). Góry były odnalezioną duchową ojczyzną, zamieszkiwaną przez ludzi wolnych, zanurzonych w oryginalnej kulturze ludowej, czerpiącej inspirację ze świata natury. Utopia tatrzańska okazała się „,alternatywą wobec innych istniejących wówczas projektów i wizji przyszłości Polski, a także nastrojów zagrożenia, jakie niósł nadchodzący wiek” (s. 103). Miejsce to spełniało również funkcję terapeutyczną wobec pesymistycznych wizji przyszłości rozwijających się u schyłku XIX wieku. Pojawiający się w wyobraźni narratora obraz Tatr kontrastuje z rachityczną przestrzenią Księżyca, nazwaną „dantejskim piekłem" (Żuławski, 1987, s. 56):

Turnie, wznosząc się przeszło na cztery tysiące metrów ponad dnem tej przepaści, spadały ku niej prawie pionowo, we wściekłych jakichś podrzutach. Wyglądało to, jakby w otchłań waliły w skoku zastygłe, o iglice poszarpane kaskady (s. 55).

Skaliste, ostre szczyty o stromych pionowych ścianach nie tylko przytłaczają bohaterów swoim rozmiarem, lecz także wywołują w nich przerażenie. Miejsce to budzi skojarzenia z obrazem Wyspa umarlych Arnolda Böcklina (1886), na którym skalista wyspa przypomina o nieuchronności ostatniej podróży. W podobnej sytuacji są bohaterowie Żuławskiego, gdyż znajdują się nad przepaścią, a panująca złowieszcza cisza potęguje w nich uczucie strachu. Zarówno u Böcklina, jak i u Żuławskiego na pierwszy plan wysuwa się opozycja człowiek - natura. Świat przyrody to potężny żywioł, w starciu z którym ludzkość, przypominająca mikroskopijne organizmy, nie ma szans na przetrwanie. Miejsce to nasuwa skojarzenia $\mathrm{z}$ typem pejzażu w malarstwie XIX-wiecznym nazwanym geologicznym, prezentującym historię planety Ziemi, w którym człowiek pełnił wyłącznie funkcję tła (Świtek, 2011, s. 70). Popularność tego gatunku wynikała z rosnącego zainteresowania geologią oraz paleontologią wśród Anglików (Piechota, 2018, s. 32-33). Przywołajmy choćby postać Mary Anning, pierwszej dziecięcej paleontolożki, która nie tylko odnalazła w Anglii kompletny szkielet ichtiozaura, lecz także założyła Old Fossil Shop, gdzie można było zakupić miejscowe okazy skamieniałości (s. 33). 
Grozę wśród bohaterów Na srebrnym globie wywołuje także trupie miasto, składające się głównie ze „spiętrzonych głazów” (Żuławski, 1987, s. 97) i nasuwające skojarzenia z kresem pewnej cywilizacji:

W oczach mi rosły coraz nowe wieżyce, łuki i kolumny, kawałki rozsypanych murów i ulice zasłane gruzem gmachów. Światło Ziemi posrebrzało te fantastyczne ruiny; z czarnego jeziora cienie wyskakiwały tajemniczo jak zjawione duchy. Przeszedł mnie dreszcz nieokreślony. Jakieś księżycowe Pompei czy Herkulanum, jeno nie z piasku wygrzebane, lecz raczej w piasek się rozsypujące straszliwe, większe, więcej trupie w tym opuszczeniu potwornym i w tym dziwnym świetle... (s. 97).

W opisie tym na pierwszy plan wysuwa się kontrastująca kolorystyka. Odbijające się światło Ziemi zamazuje kontury obiektów. Żuławski posługuje się hiperbolizacją, aby uwypuklić odczuwany przez bohaterów lęk. Dodajmy, że narrator opisuje nowe przestrzenie przez pryzmat ludzkich doświadczeń. Martwe miasto budzi skojarzenia z reliktami kultury starożytnego Rzymu.

W podobnej tonacji zostaje opisana przez Koreckiego wyspa cmentarna, stanowiąca pozostałość „większego, zaginionego w morzu lądu”, dająca „przybliżony obraz świata księżycowego i rozwijającego się na nim życia w epokach zamierzchłych" (Żuławski, 1987, s. 216). Miejsce to staje się azylem dla narratora, który niczym bohater romantyczny unika kontaktu z pozostałymi mieszkańcami planety. Wybiera samotność, a obserwacja „słońcem posrebrzonego morza” wraz z dobywającym się jednostajnym szumem fal wywołuje wspomnienia o Ziemi. Nie chodzi oczywiście o utratę tzw. kulturowego (ojczyźnianego) krajobrazu, jak u polskich romantyków, ale o utratę środowiska przyrodniczego.

\section{Flora i fauna Księżyca}

W poszukiwaniu miejsca do egzystencji bohaterowie docierają do bieguna, gdzie znajduje się "prawdziwe faliste morze”, w okolicy którego rosną lasy pełne „roślin dziwnych i nieprawdopodobnych” (Żuławski, 1987, s. 147). Miejsce to przypomina „Zaczarowane Pola Elizejskie” (s. 151):

Spojrzawszy dookoła, spostrzegłem, że się znajduję na obszernej łące wśród wzgórz, pokrytej dziwnie świeżą, puszystą zielonością. Cała okolica zalana była łagodnym półświatłem, podobnym do ziemskich świtów, gdy słońce wydostaje się dopiero spod horyzontu. Tylko nagie szczyty wysokich gór płonęły w pełnym czerwonym blasku. Nad nimi sklepiało się niebo bladobłękitne, lekką mgłą 
zaciągnięte. Patrzyłem długo, nie umiejąc sobie zdać dokładnie sprawy z tego, gdzie się znajduję. Wtedy zobaczyłem na łące dwoje ludzi, idących z wolna i schylających się co chwila, jak gdyby czegoś szukali. Dookoła nich skakały dwa psy, poszczekując wesoło (s. 148).

W pejzażu tym bezmiar łąki oddaje modernistyczną fascynację rozległymi przestrzeniami i nieskończonością (Rossa, 2003, s. 232). Na uwagę zasługują epitety złożone („bladobłękitne”, „puszysta zieleń”), które nie tylko odzwierciedlają podejmowane przez impresjonistów eksperymenty kolorystyczne, lecz także oddają lekkość oraz zwiewność owego miejsca. Przestrzeń ta jest przyjazna człowiekowi i budzi skojarzenia z opisami przyrody w tych utworach fantasy, których akcja rozgrywa się w quasi-średniowiecznej scenerii. Dominuje $\mathrm{w}$ nich wizerunek natury pierwotnej, funkcjonującej w pamięci zbiorowości jako miejsce tajemnicze, baśniowe, zamieszkałe przez istoty hybrydyczne, takie jak nimfy, boginie, smoki. Mityczne przestrzenie charakteryzują się bogatym drzewostanem o wielkich oraz niespotykanych rozmiarach, wśród których można dostrzec rzadkie oraz ginące gatunki roślin i zwierząt. Obszar ten z jednej strony zachwyca i uwodzi ludzi, z drugiej zaś bywa niebezpieczny ze względu na zamieszkujące go demony. W powieści Żuławskiego biesów zastępują duchy zmarłych, które występują w marzeniach sennych bohaterów.

W nadmorskim pejzażu Księżyca uwaga narratora koncentruje się na długich kolorowych fosforyzujących wodorostach:

Kształt ich był nader rozmaity; jedne podobne były do olbrzymich wachlarzy obwieszonych delikatną, ruchliwą frędzlą, inne znowu, nakrapiane różnymi barwami, wśród których przeważała czerwona i ciemnobłękitna, przypominały jakieś bajeczne pawie pióra. Były tam i takie, co miały brzegi wycięte w formę akantusowego liścia i najeżone kolcami, i takie, co zwinięte u dołu, tworzyły lejki, i jeszcze inne, gładkie i lśniące albo pokryte długim, żółtozielonym włosem, spadającym po obu stronach aż do ziemi - słowem, największa rozmaitość barw i kształtów, a wszystko żyjące, ruchliwe, wijące się za najlżejszym dotknięciem. Nad brzegiem strumyka, wpółzanurzone w jego kryształowej fali, ciągnęły się znowu długie wodorosty, jak rdzawozielone węże i liny, obwieszone, niby kwiatami, kręgami śnieżnej białości o silnym, upajającym zapachu (Żuławski, 1987, s. 171).

Miejsce to uwodzi narratora bogactwem kształtów oraz barw. Unoszące się liście falują, a ruch ten jest miarowy, płynny, senny. W powietrzu unosi się upajający zapach roślin, narkotyzujący mężczyznę. Bohater zwraca również uwagę na nietypowe reakcje kwiatów, które zmieniają kształt pod wpływem dotyku: 
Uciąłem jedną z nich nożem i przekonałem się, że są to wielkie, podłużne i mięsiste liście zwinięte podwójnie, naprzód $\mathrm{w}$ trąbkę, a potem w ślimak, podobnie jak rulony angielskiego tytoniu, o brunatnej, z drobnych zdrzewiałych łusek utworzonej zewnętrznej powłoce. Na stronie wewnętrznej, jasnozielonej, rozsiane były liczne różowe żyłki. Cała roślina, póki żywa, obdarzona była zdolnością ruchu, podobnie jak nasze mimozy (s. 169).

Pobyt nad strumieniem korzystnie wpływa na nastrój bohatera, który wyraża zachwyt nad pięknem i unikatowością tego ekosystemu. Narrator podkreśla, że kosmiczne rośliny stały się źródłem niezbędnej do życia wody oraz pokarmu:

Łąki tutejsze utworzone są z dziwnie soczystych roślin, podobnych do ziemskich mchów i tak samo jak one obdarzonych zdolnością wysysania wilgoci wprost $\mathrm{z}$ powietrza, tylko $\mathrm{w}$ daleko jeszcze wyższym stopniu. Gromadzą one w sobie tyle wody, że wyciskając naręcze tych porostów, otrzymywaliśmy po parę litrów tego tak cennego dla życia płynu. Napój zyskiwaliśmy zatem z łatwością, nieco gorzej było z pożywieniem. Znaleźliśmy parę gatunków soczystych roślin dających się jeść i wielką ilość ciekawych żyjątek, podobnych do dużych ślimaków bez skorupy, ale nie mieliśmy przy czym przyrządzić tej strawy (Żuławski, 1987, s. 151-152).

Warto zaznaczyć, że tajemnicze rośliny gromadzące w sobie wodę przypominają aloes, który wraz z mirrą w starożytności używany był do balsamowania zwłok (Kopaliński, 2017, s. 8). Odmienny świat flory dominuje na licznych wyspach położonych na morzu. Roślinność ta była:

[...] mniej bujna niż gdzie indziej, odznaczała się bez porównania większą rozmaitością gatunków. Na tych kilku kwadratowych kilometrach ziemi spotkałem zaledwie trzy czy cztery krzewy znane mi skądinąd, ale za to niezliczoną moc roślin, nie znachodzących się gdzie indziej. Wszystkie były dziwnie smutne i skarlałe. Patrząc na nie, nie mogłem oprzeć się wrażeniu, że mam przed sobą resztki pokolenia zmarłego i zewsząd wypartego, które się tutaj jakimś cudem ostało jeszcze, świadcząc o postaci życia na Księżycu przed wielu, wielu wiekami, kiedy tu, gdzie teraz jest morze, były lądy, a woda zalewała inne okolice (Żuławski, 1987, s. 214).

Nieprzypadkowo uwagę narratora przykuwają rośliny „dziwnie smutne i skarlałe”, które stają się czytelną egzemplifikacją Darwinowskiej teorii ewolucji, zakładającej, iż w wyniku rywalizacji międzygatunkowej jedne istoty giną, a następnie inne zajmują ich miejsce (Koziołek, 2011, s. 18). Świat przyrody 
jest niezwykle bogaty i różnorodny; to przestrzeń, w której różne organizmy rywalizują ze sobą, ulegają transformacji, dostosowując się do zmieniających się warunków egzystencji (Oramus, 2015; Piechota, 2018, s. 28-44).

Oprócz oryginalnych roślin narrator charakteryzuje również świat zwierząt zamieszkujących kosmiczny ekosystem. Żyją tu głównie bezkręgowce, mięczaki czy gady, które ukrywają się w gąszczu kwiatów oraz w okolicznych zbiornikach wodnych:

Głębie wód roiły się od szczególnych potworków, w powietrzu unosiły się jakieś latające jaszczurki, podobne z daleka do ptaków o grubej szyi i długim ogonie. Ale co szczególna - wszystkie zwierzęta na Księżycu są nieme. Brak tutaj tych niezliczonych głosów życia, które brzmią wśród ziemskich łąk i lasów; jedynie gdy wiatr powieje, szeleszczą ogromne liście tutejszych roślin, przerywając wraz ze szmerem strumienia wieczystą głuszę (Żuławski, 1987, s. 172).

W przeciwieństwie do zwierząt zamieszkujących Ziemię, na Księżycu nie wydają one dźwięków. Panuje tutaj absolutna cisza, która na terenach skalistych potęguje nastrój grozy. Narrator niczym biolog przybliża również ich sposób rozmnażania się:

[...] żadne z tutejszych stworzeń nie przychodzi na świat żywe, lecz wszystkie znoszą jaja, niesłychanie na mróz odporne, a wylęgające się nadzwyczaj szybko w słonecznym cieple. [...] Początkowo przykrzyło nam się tylko bez mięsnego pożywienia, ale teraz jużeśmy się przyzwyczaili. Wszystkie zwierzęta tutejsze mają mięso łykowate i smrodliwe tak, że jeść go nie podobna (s. 188).

Nowi mieszkańcy Księżyca zmieniają dotychczasową dietę, stając się wegetarianami. Interesujący wydaje się również stosunek bohaterów do zwierząt domowych - psów. Przypomnijmy, że wraz z kosmonautami przyleciała Selena ze szczeniętami. Wybór współtowarzyszy podróży nie wydaje się przypadkowy, gdyż w epoce wiktoriańskiej stworzenia te traktowano jako członków rodziny. Co więcej, pomagały one w radzeniu sobie ze stresem oraz samotnością w wielkim mieście (Babilas, 2015, s. 108). Mimo rosnącego niepokoju z powodu kurczących się zbiorników powietrza:

[...] nikomu nie przyszło na myśl, że można było zabić psy, które przecież także zużywały wiele powietrza i przedłużyć w ten sposób czas, jaki - sądziliśmy pozostał nam do końca życia! [...] Przez swą zwierzęcą prostotę przypominają nam one więcej Ziemię, niż my sobie możemy przypominać nawzajem swymi osobami. Z rozczuleniem patrzę na te zwierzęta... Jesteśmy tak samotni i tak strasznie od Ziemi oderwani (Żuławski, 1987, s. 89). 
Zwierzęta, które przybyły wraz z bohaterami, traktowane są jak członkowie załogi. Być może początkowy wybór diety pozbawionej mięsa wiąże się z przekonaniami religijnymi Marty, która, jak wiemy, pochodzi z Indii. Bohaterka, wierząc $\mathrm{w}$ reinkarnację, obawiała się, że zabijając niewinne stworzenia, może zablokować cykl wędrówki dusz. Warto podkreślić, iż w powieści Żuławskiego pojawia się epizod, w którym narrator porzuca perspektywę antropocentryczną na rzecz biocentrycznej, nadając pozaludzkim stworzeniom status podmiotu. Jako baczny obserwator zdarzeń rejestruje zachowanie psa, obserwującego agonię swojego opiekuna:

Selena, ulubiona jego suka, usiadła nieruchomo przy hamaku jakby na straży i nie spuszcza oka ze swego chorego pana. Jestem przekonany, że to rozumne zwierzę zdaje sobie doskonale sprawę ze stanu, w jakim się pan znajduje. W oczach jej widno tyle żałości i niepokoju... Gdy się kto z nas zbliża do chorego, ona warczy z cicha, jakby ostrzegając, że czuwa i nie da mu krzywdy zrobić, a potem wywija ogonem, aby dać poznać, że wierzy w nasze przyjazne zamiary i cieszy się naszą troskliwością (s. 102).

Między Tomaszem a zwierzęciem wytworzyła się więź będąca rodzajem komunikacji międzygatunkowej (Weil, 2012, s. 59). Narrator dostrzega w stworzeniu istotę zdolną do wyższych uczuć. Selena okazuje się bohaterką empatyczną, współodczuwającą cierpienie swojego opiekuna.

Warto podkreślić, że na początku powieści Żuławskiego dominuje obraz natury martwej, pozbawionej jakichkolwiek oznak życia. Północna część Księżyca budzi skojarzenia z bezkresną pustynią, po której niczym w labiryncie błąkają się kosmonauci. Autor posłużył się poetyką ekspresjonistyczną, podkreślającą dramatyzm sytuacji, w jakiej znaleźli się bohaterowie. Upiorne światło Ziemi przypomina im o bezpowrotnie utraconej więzi z ludzkością. Co więcej, staje się początkiem pogłębiającej się tęsknoty za dawną planetą. Narrator pamiętnika dochodzi do konstruktywnych wniosków na temat mieszkańców Ziemi:

O! ludzie nie umieją cenić piękności Ziemi! - Gdyby się dostali tutaj, gdzie my jesteśmy, kochaliby ją tak, jak my ją teraz, straconą na wieki, kochamy, i tak, jak my, śniliby o niej w stanach gorączkowych, niespokojnych, pełnych upartej a bolesnej tęsknoty... (Żuławski, 1987, s. 90).

Dopiero w kontakcie $\mathrm{z}$ odmiennym środowiskiem człowiek potrafi docenić piękno zamieszkiwanej niegdyś planety. Przypomnijmy, że zgodnie z tradycją patriarchalną ziemię traktuje się wyłącznie przedmiotowo jako naturalne 
źródło dóbr, którymi się handluje (Durczak, 2010, s. 10). Postrzegając ją w kategoriach materialnych, zapominamy o jej terapeutycznej, uzdrawiającej mocy. Przywołajmy choćby epizod, w którym umierającemu Tomaszowi Marta opowiada o Ziemi:

Na Ziemi jest powietrze błękitne, a po nim chodzą chmury. Na Ziemi jest dużo, dużo wody, całe ogromne morze. Na wybrzeżu morza jest piasek i muszle różnokolorowe, a dalej są łąki, na których kwitną takie wonne, słodkie, wilgotne kwiaty... Za łąkami znowu są lasy, pełne zwierząt i śpiewających ptaszków. Gdy wiatr zawieje, to morze huczy szeroko i lasy szumią, i trawy szeleszczą (Żuławski, 1987, s. 125-126).

Opowieść o Ziemi jako raju utraconym, do którego powróci umierający mężczyzna, napawa bohatera optymizmem. Historie opowiadane przez Martę sprawiają, iż Tomasz nie postrzega śmierci jako doświadczenia traumatycznego, lecz jako nieunikniony etap w życiu każdego człowieka.

Odmienny krajobraz dominuje w południowej części Księżyca, w której bohaterowie postanawiają się osiedlić. Żuławski posługuje się tutaj poetyką impresjonistyczną, co sprawia, że miejsce nasuwa skojarzenia z baśniami. Niespotykane rośliny i niesamowite zwierzęta nie wywołują wśród bohaterów uczucia przerażenia. Kosmonauci „wtapiają się” w ten świat, nie naruszając panującej w nim harmonii. Przestrzeń ta wydaje się wpływać kojąco na bohaterów, którzy, pogodzeni z własnym losem, akceptują fakt, że nigdy nie powrócą na Ziemię, a wspomnienia o niej urastają do rangi mitu o raju utraconym.

\section{Podsumowanie}

Bohaterowie powieści Żuławskiego wydają się „uciekinierami z Ziemi, niespokojnymi i niepokornymi naturami, zmęczonymi duchową jałowością egzystencji” (Trześniowski, 2001, s. 128). Ich wyprawa na Księżyc nosi znamiona ekspedycji naukowej, której potwierdzeniem staje się dziennik prowadzony przez narratora. Postać ta odgrywa kluczową rolę w utworze, gdyż to dzięki niemu poznajemy nieznany świat flory oraz fauny. Narrator, przemierzając przestrzeń Księżyca, niczym naukowiec systematycznie rejestruje zmiany w krajobrazie, wielokrotnie porównuje go do ziemskiego ekosystemu. Jako baczny obserwator świata przyrody odkrywa, że teoria ewolucji Darwina obejmuje nie tylko Ziemię; również tutaj dostrzega, iż rośliny oraz zwierzęta uwikłane są w proces transformacji. Osobniki słabsze przegrywają w rywalizacji międzygatunkowej 
i znikają z powierzchni Księżyca. Pojedyncze, skarlałe, słabe organizmy stają się egzemplifikacją cywilizacji, która wyginęła.

Wraz z pobytem na Księżycu zmienia się stosunek bohaterów do Ziemi. Początkowo świecąca planeta opisywana jest jako: „szklany upiór” (Żuławski, 1987, s. 30), „czarna plama” (s. 84), „sczerniały trup” (s. 160). Określenia te kojarzą się z postępującą agonią. Być może protagoniści przeczuwali nadciągającą katastrofę ekologiczną, której źródłem stał się gwałtowny rozwój przemysłu naruszający harmonię panującą $\mathrm{w}$ świecie natury. Zanieczyszczenie powietrza i rzek, wycinka lasów, masowe zabijanie zwierząt oraz liczne kataklizmy sprawiają, że życie na Ziemi przestało być bezpieczne. Z każdym kolejnym dniem bohaterowie tęsknią za dawną planetą, z którą utracili kontakt. Interesujący wydaje się fakt, że zarówno narrator, jak i Tomasz idealizują egzystencję na Ziemi. W ich wspomnieniach pojawiają się polskie góry, rzeki, lasy, jeziora. Paradoksalnie żaden z protagonistów nie tęskni za ludźmi. Wydaje się, że człowiek potrafi docenić piękno i bioróżnorodność Ziemi dopiero po jej opuszczeniu. Budując nowe społeczeństwo na Księżycu, bohaterowie pragnęli stworzyć cywilizację opartą na harmonii. Niestety, jak wiemy z kolejnych tomów Trylogii księżycowej, idea ta okazuje się mrzonką, gdyż człowiek zaślepiony egoizmem oraz zachłannością powtarza dawne błędy ludzkości.

Niewątpliwie powieść Żuławskiego stała się inspirująca dla młodych czytelników zafascynowanych podróżami międzyplanetarnymi. Na początku XX wieku była ona cennym źródłem informacji na temat ukształtowania powierzchni Księżyca oraz występujących na nim formacji geologicznych (m.in. dolin, gór, klifów, kraterów, morza). Dzisiaj wydaje się utworem zapomnianym, mimo że przypomina koncepcyjnie powieść Eden Stanisława Lema (1984), należącą do klasyki science fiction. Moim zdaniem trylogia Żuławskiego odczytywana z perspektywy ekokrytycznej kryje w sobie potencjał, aby ponownie zainteresować współczesną młodzież, która w przeciwieństwie do starszej generacji jest świadoma zagrożeń wynikających z pogłębiającego się kryzysu klimatycznego (o czym świadczą licznie organizowane przez młodych ludzi protesty). Ekokrytyczna lektura powieści z wyeksponowanym wątkiem ucieczki bohaterów z Ziemi nasuwa skojarzenia $\mathrm{z}$ utworami dystopijnymi (gatunkiem niezwykle popularnym wśród nastolatków), rozgrywającymi się często w światach po katastrofach naturalnych wywołanych przez człowieka (Oramus, 2010, s. 178-198). Czytana dzisiaj, powieść Żuławskiego może być impulsem do podjęcia głębszej refleksji na temat globalnego kryzysu ekologicznego, spowodowanego przez nadmierną ingerencję człowieka w ekosystem. 


\section{Bibliografia}

Alighieri, D. (1978). Boska komedia (E. Porębowicz, tłum.). PIW. (wyd. oryg. 1472).

Babilas, D. (2015). Psy maskotki i rodzinni pupile w malarstwie brytyjskim epoki wiktoriańskiej. W: E. Łoch, A. Trześniewska, D. Piechota (red.), Emancypacja zwierzat? (s. 105-118). LTN.

Barcz, A. (2012). Przyroda - bliska czy daleka? Ekokrytyka i nowe sposoby poetyki odpowiedzialności za przyrodę w literaturze. Anthropos?, 18-19, 60-79.

Barcz, A. (2013). Realność ekosystemu w Placówce Bolesława Prusa. W: E. Paczoska, B. Szleszyński, D. M. Osiński (red.), Realiści, realizm, realność. W stulecie śmierci Bolestawa Prusa (s. 149-160). NCN.

Bloch, J. (1893). Przyszła wojna, jej ekonomiczne przyczyny i skutki. Gebethner i Wolff.

Bloch, J. (1899). Wnioski ogólne z dzieła Przyszła wojna pod względem technicznym, politycznym, ekonomicznym. Gebethner i Wolff.

Colomb, P. H. (1893). The great war of 189-: A forecast. W. Heinemann.

Cromie, R. (2015). The crack of doom [wydanie elektroniczne]. Duke Classics. (wyd. oryg. 1895).

Domańska, E. (2013). Humanistyka ekologiczna. Teksty Drugie, 1-2, 13-32.

Durczak, J. (2010). Rozmowy z ziemia. Tradycja przyrodopisarska w literaturze amerykańskiej. Wydawnictwo UMCS.

Fiedorczuk, J. (2015). Cyborg w ogrodzie. Wprowadzenie do ekokrytyki. WN Katedra.

Gielata, I. (2015). Nie-dostrzeżone historie - o „życiu bez ruchu”. W: E. Łoch, A. Trześniewska, D. Piechota (red.), Emancypacja zwierząt? (s. 149-163). LTN.

Gielata, I. (2016). „Oko Emersona” i „oko Darwina” - Dickens, Sienkiewicz i wodospad Niagara. W: M. Gloger, T. Sobieraj (red.), Między przyrodoznawstwem a humanistyką. Przestrzenie kultury polskiego pozytywizmu (s. 115-125). Semper.

Gifford, T. (2000). Pastoral, anti-pastoral, post-pastoral. W: L. Coupe (red.), The green studies reader: From romanticism to ecocriticism (s. 219-222). Routledge.

Hutnikiewicz, A. (2002). Młoda Polska (wyd. 8). WN PWN.

Ihnatowicz, E. (2000). Literatura polska drugiej połowy XIX wieku (1863-1918). Trio.

Kordylewski, K. (1987). Uwagi astronoma. W: J. Żuławski, Na srebrnym globie. Rękopis z Księżyca (wyd. 6, s. 331-335). Wydawnictwo Literackie.

Kopaliński, W. (2017). Aloes. W: Słownik symboli (s. 8). Rytm.

Koziołek, R. (2010). Biologia literatury. Świat i Słowo, 14(1), 63-74.

Koziołek, R. (2011). Kompleks Darwina. Teksty Drugie, 3, 11-32.

Kronenberg, A. (2014). Geopoetyka. Związki literatury i środowiska. Wydawnictwo UŁ. Laird Clowes, W. (1892). The captain of the "Mary Rose”: A tale of tomorrow. Tower. Lem, S. (1984). Eden (wyd. 4). Wydawnictwo Literackie. 
Leszczyński, G. (2002). Powieść fantastycznonaukowa, powieść science fiction. W: B. Tylicka, G. Leszczyński (red.), Słownik literatury dziecięcej i młodzieżowej (s. 315-316). Zakład Narodowy im. Ossolińskich.

Łoch, E. (red.). (1976). Jerzy Żuławski, życie i twórczość. Referaty i materiały Sesji Naukowej. Towarzystwo Naukowe.

Majewski, E. (1890). Doktor Muchołapski. Fantastyczne przygody w świecie owadów. Gebethner i Wolff.

Majewski, E. (1898). Profesor Przedpotopowicz. Gebethner i Wolff.

Makuch, D. W. (2015). Zalety kulturowej teorii gatunku w pracy historyka literatury na przykładzie polskiej fantastyki naukowej drugiej połowy XIX wieku. W: E. Bulisz, M. Wojtak (red.), Porozmawiajmy o gatunkach - artystycznych $i$ użytkowych (s. 31-46). Wydawnictwo UMCS.

Morrison, J. L. (1969). A view of the Moon from the Sun: 1835. American Heritage, 20(3). Pobrane 24 stycznia 2020 z: https://www.americanheritage.com/viewmoon-sun-1835\#2.

Nazaruk, E. (2011). Ewa niejedno ma imię - literacka prezentacja Jerzego Żuławskiego. W: E. Łoch, D. Trześniowski (red.), Zasługi Jerzego Żuławskiego i jego rodu dla literatury i kultury polskiej XX wieku (s. 141-151). Wydawnictwo UMCS.

Oramus, D. (2010). O pomieszaniu gatunków. Science fiction a postmodernizm. Trio.

Oramus, D. (2015). Darwinowskie paradygmaty. Mit ewolucji w kulturze wspótczesnej. Copernicus Center Press.

Oramus, D. (2020). Stany splątane. Fizyka a literatura współczesna. Copernicus Center Press.

Osterhammel, J. (2013). Historia XIX wieku. Przeobrażenie świata (I. Drozdowska-Boering, A. Peszke, J. Kałążny, K. Śliwińska, tłum., wyd. 2 popr.). Wydawnictwo Poznańskie. (wyd. oryg. 2009).

Paczoska, E. (1996). Zakopiańskie środowisko artystyczne przełomu wieków. Poszukiwania intelektualne i duchowe. W: E. Rekłajtis (red.), Wybory wartości. Inteligencja polska u schyłku XIX i na początku XX wieku (s. 101-123). EL-Press.

Paczoska, E. (2008). Lalka, czyli rozpad świata (wyd. 2). Wydawnictwa Akademickie i Profesjonalne.

Paczoska, E. (2010). Prawdziwy koniec XIX wieku. Śladami nowoczesności. PIW.

Panasiuk, K. (2013). Konwencja fantasy w obiektywie kamery filmowej. Analiza filmu Na srebrnym globie Andrzeja Żuławskiego. W: J. Szcześniak (red.), Fantastyka XIX-XXI wieku. Kanon i obrzeża. Część II (s. 139-150). Wydawnictwo UMCS.

Piechota, D., Trześniewska, A. (2016). Zwierzęta w orbicie fantastyki przełomu XIX i XX wieku. W: A. Mik, P. Pokora, M. Skowera (red.), Czytanie menażerii. Zwierzęta w literaturze dziecięcej, młodzieżowej i fantastycznej (s. 153-172). Wydawnictwo SBP.

Piechota, D. (2016). (Nie)znane życie owadów. O mikroprzestrzeni w powieści Erazma Majewskiego Doktor Muchołapski. W: W. Kostecka, M. Skowera (red.), Geografia 
krain zmyślonych. Wokót kategorii miejsca i przestrzeni w literaturze dziecięcej, młodzieżowej i fantastycznej (s. 327-336). Wydawnictwo SBP.

Piechota, D. (2018). Pozytywistów spotkania z natura. Szkice ekokrytyczne. WN Katedra. Podraza-Kwiatkowska, M. (2001). Literatura Młodej Polski (wyd. 4). WN PWN.

Pułka, L. (1996). Hołota, masa, tłum. Bohater zbiorowy w prozie polskiej 1890-1918. Wydawnictwo UWr.

Rąbkowska, E. (2017a). Dzieci, zwierzęta i wielka zabawa. Przekształcenia wątków zwierzęcego folkloru w polskiej literaturze dla dzieci i młodzieży w perspektywie kulturowych studiów nad zwierzętami (cultural animal studies). Polonistyka. Innowacje, 5, 85-101.

Rąbkowska, E. (2017b). Zwierzęta i ich dzieci - poznanie, empatia, etyka. Perspektywa ekokrytyczna w literaturze dla dzieci i młodzieży. W: P. Czapliński, J. B. Bednarek, D. Gostyński (red.), Literatura i jej natury. Przewodnik ekokrytyczny dla nauczycieli i uczniów szkót średnich (s. 37-48). Rys.

Rossa, A. (2003). Impresjonistyczny świat wyobraźni. Poetycka i malarska kreacja pejzażu. Studium wybranych motywów. TAiWPN Universitas.

Rybicka, E. (2018). Biopolis - przyroda i miasto. Teksty Drugie, 2, 57-74.

Sienkiewicz, H. (1880). Listy z podróży do Ameryki. Gebethner i Wolff.

Sinclair, U. (1949). Grzęzawisko (A. Niemojewski, tłum.). Książka i Wiedza. (wyd. oryg. 1906).

Skowera, M. (2016). Literackie spotkania istot podporządkowanych. Studium przypadku: Miasteczko Ostatnich Westchnień Grzegorza Gortata. W: A. Mik, P. Pokora, M. Skowera (red.), Czytanie menażerii. Zwierzęta w literaturze dziecięcej, młodzieżowej i fantastycznej (s. 53-74). Wydawnictwo SBP.

Spengler, O. (2014). Zmierzch Zachodu. Zarys morfologii historii powszechnej (J. Marzęcki, tłum.). Aletheia. (wyd. oryg. 1918).

Sroczyńska, K. (2018). Jak Słońce odkryło życie na Księżycu. Przekrój, 4, 30-33.

Szcześniak, J. (2011). Jerzy Żuławski i Antoni Lange w orbicie fantastyki. W: E. Łoch, D. Trześniowski (red.), Zasługi Jerzego Żuławskiego i jego rodu dla literatury i kultury polskiej XX wieku (s. 129-140). Wydawnictwo UMCS.

Szurek, J. (1988). Tendencje ekspresjonistyczne w prozie Jerzego Żuławskiego. W: E. Łoch (red.), Ekspresjonizm w literaturze Młodej Polski na tle literatury polskiej i obcej XX wieku (s. 183-214). Wydawnictwo UMCS.

Świtek, G. (2011). Darwin, darwinizm i kultura wizualna XIX wieku. Teksty Drugie, 3, 64-82.

Tabaszewska, J. (2018). Ekokrytyczna (samo)świadomość. Teksty Drugie, 2, 7-15.

Tracy, L. (1896). The final war. G. P. Putnam.

Tripplin, T. (1858). Podróż po Księżycu, odbyta przez Serafina Bolińskiego. Bolesław Maurycy Wolff. 
Trześniewska-Nowak, A. (2020). Profesora Przedpotopowicza poszukiwania źródeł natury na podstawie powieści Erazma Majewskiego Profesor Przedpotopowicz. W: E. Łoch, A. Trześniewska-Nowak, D. Piechota (red.), (Nie)zapomniane zwierzęta (s. 37-55). WN Katedra.

Trześniewska, A., Piechota, D. (red.). (2016), Ekomodernizmy. Norbertinum.

Trześniowski, D. (2001). Jerzego Żuławskiego „światło ze Wschodu”. W: J. Szcześniak, D. Trześniowski (red.), Modernistyczny wizerunek człowieka. Studia historycznoliterackie (s. 121-136). UMCS.

Trześniowski, D. (2003). Młodopolskie źródła fantasy. Trylogia księżycowa Jerzego Żuławskiego. W: M. Dąbrowski, A. Z. Makowiecki (red.), Modernistyczne źródła dwudziestowieczności (s. 199-208). Wydawnictwa UW.

Ubertowska, A. (2013). Natura u kresu (ekocyd). Teksty Drugie, 1-2, 33-44.

Ubertowska, A. (2018). „Mówić w imieniu biotycznej wspólnoty”. Anatomie i teorie tekstu środowiskowego/ekologicznego. Teksty Drugie, 2, 17-40.

Utkowska, B. (2011). „Społeczeństwo to absurd” - katastrofizm antyutopijny Jerzego Żuławskiego i Władysława Reymonta. W: E. Łoch, D. Trześniowski (red.), Zasługi Jerzego Żuławskiego i jego rodu dla literatury i kultury polskiej XX wieku (s. 113127). Wydawnictwo UMCS.

Weil, K. (2012). Thinking animals: Why animal studies now?. Columbia University Press.

Wells, H. G. (1987). Wojna światów (H. Józefowicz, tłum.). Iskry. (wyd. oryg. 1898).

Wells, H. G. (1991). Pierwsi ludzie na Księżycu (W. Chwalewik, tłum.). Krajowa Agencja Wydawnicza. (wyd. oryg. 1901).

Wietecha, A. (2016). Świat zwierząt i roślin uwikłany w świat ludzi w Emancypantkach Bolesława Prusa. W: A. Trześniewska, D. Piechota (red.), Ekomodernizmy (s. 45-53). Norbertinum.

Wojciechowski, K. (2018). Ekokrytyka. WBPiCAK.

Żuławski, A. (reż.). (1987). Na srebrnym globie [film]. Zespół Filmowy Kadr.

Żuławski, J. (1910). Zwycięzca. Gebethner i Wolff.

Żuławski, J. (1911). Stara Ziemia. Gebethner i Wolff.

Żuławski, J. (1987). Na srebrnym globie. Rękopis z Księżyca (wyd. 6). Wydawnictwo Literackie. 